\author{
Aleksandra Chomiuk \\ Wydział Humanistyczny \\ Uniwersytet Marii Curie-Skłodowskiej w Lublinie \\ e-mail: aleksandra@poczta.umcs.lublin.pl \\ ORCID: 0000-0002-3236-615X
}

\title{
Przeszłość pod nadzorem. O filmie historycznym $w$ PRL
}

Film historyczny $\mathrm{w}$ dobie PRL to temat książki Piotra Kurpiewskiego ${ }^{1}$ wpisującej się w coraz bogatszy zasób prac dotyczących związków historii i filmowego widowiska. Same owe powiązania są obecnie rozumiane na różne sposoby. W najbardziej oczywistym ujęciu chodzi o opis historycznych przemian filmu, czasem również $\mathrm{w}$ zespoleniu $\mathrm{z}$ przekształceniami instytucjonalno-technicznych uwarunkowań jego powstawania (byłby on wtedy dokumentem z zakresu szeroko rozumianej historii kina). Dalej można mówić o postrzeganiu kinowych opowieści jako form upowszechniania wiedzy na temat przeszłości, kiedy to najważniejszym problemem ich opisu staje się stopień zgodności z podręcznikową faktografią, następnie - odwołując się do tytułu pionierskiego tekstu Bolesława Matuszewskiego - o ich rolę jako „nowego źródła historii”, wizualno-akustycznego zapisu rzeczywistości przydatnego do badań nad epoką, w której powstały ${ }^{2}$. Wreszcie, w kontekście narratywistycznych ujęć historiografii odkrywającej swoje uwikłania literackie, a także wraz z przejściem od kultury werbalnej do audiowizualnej, pojawiła się możliwość nadania filmowej opowieści statusu podobnego do prac historycznych. Film można więc, za Haydenem White'm, scharaktery-

\footnotetext{
1 P. Kurpiewski, Historia na ekranie Polski Ludowej, Gdańsk 2017.

2 Zob. B. Matuszewski, Nowe źródło Historii, przeł. B. Michałek, w: Film i historia. Antologia, red. I. Kurz, Warszawa 2008, s. 19-24.
} 
zować jako historiofotię, czyli „reprezentacj[ę] historii i refleksji nad nią tworzon[ą] w obrazach wizualnych i w dyskursie filmowym"3. Owa reprezentacja podlega jednak, podobnie jak historiografia, ograniczeniom poznawczym wynikającym z "rodzinnego podobieństwa” narracji historycznych i fikcyjnych, uzależnionych od tych samych schematów fabularnych i poddanych podobnym konwencjom i praktykom reprezentacji ${ }^{4}$.

Odpowiedź na pytanie o to, do których z wyliczonych wyżej nurtów opisu filmu historycznego odwołuje się Kurpiewski, poprzedzę opisem założeń jego publikacji i przybliżeniem zastosowanego w niej porządku. Celem autora stało się, jak sam podkreśla, całościowe omówienie "gatunku polskiego filmu historycznego czasów PRL" [s. 10]. Badacz deklarujący się "[j]ako historyk z filmoznawczym zacięciem", postawił sobie dwa szczegółowe zadania. Chodziło po pierwsze o „pokazanie politycznych meandrów powstawania filmów historycznych w Polsce Ludowej", po drugie zaś o "opis analizowanych dzieł pod kątem ich wartości estetycznej, która dla widzów stanowi najważniejsze kryterium oceny utworu filmowego" [s. 13].

Praca składa się ze wstępu zawierającego objaśnienia terminologiczne, zarysowującego ideologiczne uwarunkowania peerelowskich produkcji filmowych i skrótowo przybliżającego dzieła przedwojenne (do tej części książki jeszcze wrócę), pięciu rozdziałów, wkładki z fotosami, bibliografii, indeksu osobowego oraz indeksu filmów. Dzieła filmowe zostały zaprezentowane $\mathrm{w}$ chronologicznym porządku ich powstawania, począwszy od dokonań podporządkowanych doktrynie socrealizmu, przez okres gomułkowski, gierkowski (z dodatkowym rozdziałem dotyczącym przełomu między dekadą lat sześćdziesiątych i siedemdziesiątych), aż po lata osiemdziesiąte XX wieku. Podstawą materiałową badań stały się same filmy (przy okazji należałoby zapytać o to, gdzie zagubił się deklarowany we wstępie ich bibliograficzny wykaz), archiwalia związane z poszczególnymi produkcjami: protokoły Komisji Ocen Scenariuszy, komisji kolaudacyjnych, zapisy z posiedzeń innych politycznych gremiów wpływających na ostateczny kształt owych dzieł, scenopisy i scenariusze, a także dokumenty regulują-

${ }^{3}$ H. White, Historiografia $i$ historiofotia, przeł. Ł. Zaremba, w: Film i historia, s. 117. Innym określeniem owych filmowo-historycznych relacji stało się pojęcie historii wizualnej.

${ }^{4} \mathrm{O}$ Wittgensteinowskim podobieństwie rodzinnym pisarstwa historycznego i literackiego pisał H. White w artykule Przeszłość praktyczna, przeł. A. Czarnacka, w: Teoria wiedzy o przeszłości na tle wspótczesnej humanistyki, red. E. Domańska, Poznań 2010, s. 71. Na temat konwencji kształtujących historie wizualne zob. też R. A. Rosenstone, Historia w obrazach/historia w stowach: rozważania nad możliwościa przedstawienia historii na taśmie filmowej, przeł. Ł. Zaremba, w: Film $i$ historia, s. 106-107. 
ce kwestie kinematograficzne. Ostatnim zbiorem wykorzystanych materiałów były drukowane $\mathrm{w}$ prasie recenzje. Należy jeszcze dodać, że publikacja stanowi w autorskim zamyśle pierwszą część „naukow[ej] refleksj[i] nad wszystkimi produkcjami fabularnymi o przeszłości nakręconymi w PRL" [s. 13]. Dotyczy ona bowiem jedynie tych dzieł, których akcja rozgrywa się do połowy lat 60. XIX wieku. Kolejne części opracowania miały objąć fabuły dotyczące lat 1870-1918 i 1919-1939.

Od pierwszego rozdziału daje się dostrzec pewien analityczny modus operandi autora. Poszczególne obrazy zostają przedstawione od etapu scenariuszowego (wraz z cenzorskimi ingerencjami), przez skierowanie dzieła do produkcji, decyzję o dystrybucji, aż po jego prasową recepcję. Dodatkowym elementem opisów stało się obszerne streszczenie fabuł powiązane z komentarzami dotyczącymi ich ideologicznego wymiaru. Jeśli natomiast chodzi o deklarowane przez Kurpiewskiego zagadnienia filmowej estetyki, to przybierają one formę umieszczanych na końcu rozdziałów krótkich i na ogół dość ogólnikowych uwag dotyczących kompozycyjno-scenograficznych walorów filmów powstałych w danym okresie.

Na podstawie prezentacji zawartości książki wyraźnie widać, że mamy tu do czynienia $z$ projektem historycznym $w$ podwójnym sensie. Autor przedstawia dzieje jednego z nurtów polskiej kinematografii, eksponując jego instytucjonalne uwarunkowania i osadzając poszczególne produkcje $\mathrm{w}$ meandrach powojennego życia politycznego. Jednocześnie postrzega on prezentowaną w nich przeszłość nie tyle, ,jjaką, była naprawdę", co jako ukształtowaną (i zdeformowaną) przez politykę historyczną komunistycznych władz, a więc widzi w tych filmach dokument czasów, w których powstały. Szukając więc dla pracy metodologicznego kontekstu, można mówić o jej bliskości wobec nurtu badań określanych mianem nowej historii filmu. We wstępie do publikacji pod takim właśnie tytułem czytamy:

filmy są kształtowane i determinowane przez połączenie procesów historycznych (w tym, choć nie tylko, ograniczeń ekonomicznych, praktyk przemysłowych, strategii produkcji studyjnej i relacji z organami zewnętrznymi, takimi jak oficjalne agencje, rady ds. finansowania i cenzorzy) z indywidualną sprawczością (reprezentującą kompetencje twórcze i kulturalne ich [filmowych] dyrektorów artystycznych, kompozytorów, projektantów kostiumów, reżyserów, wydawców, producentów, gwiazd, pisarzy itp. $)^{5}$.

5 The New Film History. Sources, Methods, Approaches, ed. by J. Chapman, M. Glancy and S. Harper, London 2007, s. 6. 
Na polskim gruncie do założeń nowej historyczności odwoływali się autorzy artykułu zamieszczonego w „Kwartalniku Filmowym” z roku 2014, formułujący postulaty odnośnie do poszerzenia sposobów opisu kina doby PRL-u ${ }^{6}$.

Należy jednak podkreślić, iż owe domyślne powinowactwa między przynajmniej częścią teoretycznych postulatów badawczych nowej historii filmu a praktyką Kurpiewskiego nie zostały przez niego w żaden sposób zwerbalizowane. Autor nie deklaruje odwołań do tego nurtu badań nad kinem, choć z pewnością korzysta z niektórych jego dokonañ ${ }^{7}$. Co więcej, cała zarysowana we wstępie książki świadomość metodologiczna wydaje się ograniczać do kilku raczej powierzchownych twierdzeń. Zabrakło tam bowiem zarówno eksplicytnie wyłożonego sposobu rozumienia dokumentarnego (źródłowego) statusu filmowego obrazu, jak też jakiejkolwiek wykładni dotyczącej jego funkcji poznawczej. O trudnościach metodologicznych świadczy już sam sposób skonstruowania wstępu, który łączy zagadnienia historii wizualnej oraz genologicznej specyfiki filmu historycznego. Jeśli pierwsze zostało zasygnalizowane na dwu stronach, to dalszych dwanaście badacz poświęca odwołaniom do rozmaitych, publicystycznych i naukowych wypowiedzi na temat cech gatunku, nie tylko jednak nie dochodząc do żadnych własnych konkluzji, ale i mieszając problemy definicyjne $\mathrm{z}$ dotyczącymi typów i funkcji filmowych opowieści historycznych.

Ten wyjściowy brak skutkuje kolejnymi wątpliwościami dotyczącymi sposobu rozumienia wpisanej $\mathrm{w}$ gatunkową nazwę historyczności i tego, na jakiej podstawie autor oddzielił, $\mathrm{w}$ odniesieniu do badanych fabuł, przeszłość od współczesności. Wspomniane wyżej cytowanie słownikowych i prasowych opisów niczego nie przybliża, a arbitralność granicy między filmem historycznym i współczesnym (niehistorycznym?) ustanowionej na roku wybuchu II wojny kieruje nas z powrotem do pytania o sposób rozumienia przez Kurpiewskiego relacji między nieistniejącą przeszłością a jej filmowym obrazem. Co więcej, doprecyzowania domaga się również szerszy problem statusu historii jako nauki o dziejach. Deklarowane za Richardem Rorty'm na początku książki pragmatywistyczno-narratologiczne zdystansowanie wobec referencyjności jakichkolwiek narracji historycznych szybko bowiem przekształca się w mniej radykalne założenie o su-

6 Zob. P. Zwierzchowski, K. Kornacki, Metodologiczne problemy badania kina PRL-u, „Kwartalnik Filmowy" 2014, nr 85 (145), s. 28-39.

7 Np. przez odwołania do Edwarda Zajička jako prekursora badań nad polskim kinem $\mathrm{w}$ jego aspekcie instytucjonalno-produkcyjnym w książce Poza ekranem. Kinematografia polska 1918-1991, Warszawa 1992 (wyd. drugie uzup. i rozsz., 2009). 
biektywizacji obrazów przeszłości w filmowych opowieściach wynikające $\mathrm{z}$ "aktualnego stopnia rozwoju nauki historycznej w momencie tworzenia filmu, czynników produkcyjno-politycznych oraz osobistych pobudek reżysera i jego założeń twórczych" [s. 10]. Tym samym dostrzeżony w dziełach peerelowskiej kinematografii proces "tworzenia historii na nowo" zostaje zobrazowany głównie w kontekście wymuszonego ideologicznymi wymogami epoki sprzeniewierzenia się przez część filmowców historycznemu obiektywizmowi.

Jaki jest więc stosunek badacza do przywołanych we wstępie teoretycznych koncepcji autorów takich, jak: Marc Ferro, Robert A. Rosenstone czy Hayden White, nakładających na filmowe opowieści o przeszłości nowego typu zobowiązania poznawcze? Niestety, tego się nie dowiadujemy, wszelkie bowiem rozważania na temat historii wizualnej czy historiofotii pojawiają się hasłowo jedynie we wstępie i nie zostają wykorzystane w dalszej części publikacji, o czym wyraźnie zaświadcza jej indeks osobowy. Sama też bibliografia składa się zresztą $\mathrm{z}$ absolutnie minimalnego zasobu tekstów wzmacniających filmoznawczy wymiar książki. Nie tylko bowiem brak tu odwołań do prac dotyczących nowej historii filmu czy do innych opracowań ważnych z perspektywy przemian sposobów opisu kina historycznego, takich jak choćby History on Film/Film on History (2005) Roberta A. Rosenstone'a czy Writing History in Film (2006) Williama Guynna, ale nawet niektóre z tekstów znajdujących się w bibliografii, jak książka Anny Misiak o filmowej cenzurze ${ }^{8}$, nie zyskują $\mathrm{w}$ indeksie ani jednego odniesienia.

Niezależnie też od wartości rekonstrukcyjnych działań Kurpiewskiego szczegółowo przedstawiającego indywidualne przypadki filmowego ideologizowania przeszłości, zbyt mało jest w niej ogólniejszych refleksji na temat społeczno-kulturowej specyfiki kina historycznego Polski Ludowej zarówno w odniesieniu do szerzej pojmowanych strategii legitymizowania w nim „nowej pamięci" ", jak i w związku z poszukiwaniami przez filmowców sposobów uwiarygodniania prezentowanej wizji dziejów. Brakuje tu również szerzej zarysowanej perspektywy odbiorczej, która jest przecież czymś więcej niż tylko zapisem praktyk recenzenckich narzucających „właściwe” odczyta-

\footnotetext{
8 A. Misiak, Kinematograf kontrolowany. Cenzura filmowa w kraju socjalistycznym i demokratycznym (PRL i USA). Analiza socjologiczna, Kraków 2006.

9 Przywołuję to pojęcie w znaczeniu, w jakim użył go Piotr Zwierzchowski, dla którego „nowa pamięć” to pamięć zbiorowa uzależniona od polityki (ośrodka władzy), legitymizująca jej działania, ale także odwołująca się do społecznych stereotypów i resentymentów, zawłaszczająca i użytkująca przeszłość, kanonizująca ją lub deprecjonująca [P. Zwierzchowski, Kino nowej pamięci. Obraz II wojny światowej w kinie polskim lat 60., Bydgoszcz 2013, s. 9-10].
} 
nie filmu (wyeksponowana w pracy rola recenzentów ustawia ich raczej jako ostatnie ogniwo łańcucha produkcyjnego), odnosi się bowiem przykładowo również do podlegających porównawczym ocenom zestawień dotyczących liczby widzów poszczególnych obrazów. Niezależnie przecież od sposobów zawyżania kinowej frekwencji, np. przez zorganizowane seanse, abstrahując także od konieczności uwzględnienia momentu dystrybucji (czym innym była przecież klęska frekwencyjna filmu w latach 50. kiedy to polskie produkcje absolutnie dominowały, czym innym w latach 70., gdy repertuar uległ znacznemu wzbogaceniu o ważne dokonania kinematografii zachodniej, a jeszcze czymś innym na przełomie lat 80 . i $90 .$, kiedy polskie produkcje zaczęły przegrywać z amerykańskimi blockbusterami "nowej przygody"), to przecież właśnie liczba sprzedanych biletów ujawnia najbardziej wymierny stosunek widowni do tych dzieł.

Widz filmowy pozostał w pracy Kurpiewskiego „wielkim niemową" także ze względu na brak odwołań do głosów tzw. zwykłych odbiorców, zamieszczanych od czasu do czasu w prasie społeczno-kulturalnej. Pojawiają się one jako komponent recepcyjnego obrazu szczególnie istotny w odniesieniu do nurtu ekranizacyjnego, o czym świadczą zapisane np. w "Ekranie” czy w „Kulturze" przykłady ogólnonarodowych dyskusji dotyczących filmów sienkiewiczowskich. Ogromny społeczny odzew na ów nurt adaptacyjny łączy się zresztą z kolejnym kontekstem kina historycznego, bez którego zrozumienie tak działań reżyserskich, jak i decyzji gremiów kierujących filmowe projekty do produkcji, nie byłoby pełne. Chodzi tu o związek polskiej kinematografii z kulturą literacką, której wpływ na społeczną pamięć jest nie do przecenienia. Jeśli bowiem polskie filmy historyczne mają jakąś swoją specyfikę, to jest nią fakt, że najważniejsze (a jednocześnie najpopularniejsze) były adaptacjami powieściowej klasyki. W sytuacji zaś gdy „nowa pamięć" kształtowana przez komunistyczne władze zderzała się z pamięcią wspólnotową ukonstytuowaną dzięki utrwalonemu literacko obrazowi przeszłości, klęskę ponosiła ta pierwsza. Jednym z przykładów może tu być odrzucenie przez widzów filmu Podhale w ogniu w reżyserii Jana Batorego, marksistowskiej, klasowej reinterpretacji Sienkiewiczowskiej wizji XVII wieku.

Przykładem zbyt słabo, moim zdaniem, wykorzystanego kontekstu ideowego filmów historycznych z lat 60. ubiegłego wieku jest twórczość Zbigniewa Załuskiego, którą można uznać za emanację dokonywanych w tej dekadzie przez komunistyczną władzę przewartościowań narodowej tradycji. Kurpiewski co prawda pisał o autorze Przepustki do historii w odniesieniu do filmowych Popiotów, ale postrzegał go bardziej jako polemistę Andrzeja Wajdy niż jako ideologa nadającego swymi popularnymi książkami ton w pu- 
blicystycznych dyskusjach na temat polskiej mitologii narodowej i wychowawczej roli przeszłości. Tymczasem to właśnie wkomponowana w szerszy dyskurs polityczny lat 60. publicystyka Załuskiego współkształtowała istotne dla dziejów filmu doby PRL-u przejście od kina - jak go można umownie określić - klasowego do narodowego.

Sprowadzenie więc ewolucji w podejściu do przeszłości w filmach lat 60 . i 70., tak jak to robi Kurpiewski, do różnic między rozmachem inscenizacyjnym i eksponowaniem myśli historiozoficznej w tych pierwszych, a zwiększaniem wiarygodności obrazów dzięki detalowi historycznemu, w drugich [s. 230] jest sporym uproszczeniem owych przemian. Przy okazji ciekawym zagadnieniem jest wykorzystywanie autorytetów ze świata nauki jako alibi dla zmian scenariuszowych. Różnicę w podejściu historycznych konsultantów do filmowej materii dobrze widać w zestawieniu Krzyżaków Aleksandra Forda (1960) i Potopu Jerzego Hoffmana (1974). Podczas gdy zadaniem Stefana Kuczyńskiego stało się uwiarygodnienie antyniemieckości filmu Forda, Adam Kersten poszukiwał wraz z reżyserem Potopu kompromisu między Sienkiewiczowską wizją przeszłości, współczesną wiedzą historyczną i pragmatyką filmowej fabuły. Można tu oczywiście mówić o indywidualnych różnicach $\mathrm{w}$ rozumieniu tak założeń adaptacji, jak i istoty filmowej historyczności, nie należy też jednak abstrahować od politycznych zmian, jakie zaszły w ciągu kilkunastu lat dzielących oba filmy.

Wreszcie powroty przez filmowców do tych samych tematów czy okresów historycznych dawały Kurpiewskiemu większe możliwości wskazywania i wyjaśniania przemian $\mathrm{w}$ postrzeganiu danego momentu czy postaci z przeszłości (filmy o Barbarze Radziwiłłównie z okresu międzywojnia i $\mathrm{z}$ lat 80.; XIX-wieczne historie rewolucyjno-powstańcze tworzone $\mathrm{w}$ latach 70. i 80.; obrazy osnute wokół Napoleona i jego wojen z lat 60. i z końca 80.). W ogóle nadmiar u niego linearności i prostej sprawozdawczości, a za mało miejsc węzłowych zbierających podobieństwa i różnice, a więc ukazujących przemiany polskiej kinematografii w całej jej polityczno-kulturowej dynamice. Unikanie syntetyzujących ujęć jest tym bardziej dyskusyjne w kontekście niezwykle skrótowego podsumowania książki, co zostało przez autora objaśnione cząstkowością zawartego w niej opisu, dotyczącego zaledwie jednej trzeciej zgromadzonego materiału filmowego. Nie wydaje mi się jednak owa cząstkowość - notabene bardzo niekorzystnie wpływająca na konstrukcyjne założenia pracy - wystarczającym alibi dla rezygnacji z uogólnienia na temat zmieniających się przez ponad cztery dekady sposobów użytkowania historii przez filmowe medium. Niezależnie bowiem od zaplanowanych kolejnych publikacji dzieło zostało wydane jako całość i jako takie powinno się tłumaczyć. 
Podsumowując: opracowanie Kurpiewskiego to przykład opartej na archiwalnej kwerendzie rekonstrukcji, której przedmiotem jest przede wszystkim okołofilmowe życie polityczne w powojennym czterdziestopięcioleciu. Wartość książki wynika głównie z bogatej faktografii dotyczącej dziejów poszczególnych filmowych produkcji reprezentujących nurt gatunkowy filmu historycznego. Skrupulatnie wymieniane etapy procesu powstawania filmów stanowią jednak powtarzalną w gruncie rzeczy sekwencję działań, a oglądana z tej perspektywy peerelowska kinematografia ujawnia głównie to, o czym wiemy skądinąd, a co z pewnością nie jest całą o niej prawdą, swoją miałkość i schematyzm. Należy więc mieć nadzieję na to, że kolejne części projektu badawczego Piotra Kurpiewskiego zostaną już skonstruowane według innego klucza niż prosta chronologia.

\section{Bibliografia}

Chapman James, Glancy Mark, Harper Sue [eds.] (2007), The New Film History. Sources, Methods, Approaches, London: Palgrave Macmillan.

Matuszewski Bolesław (2008), Nowe zródło Historii, przeł. B. Michałek, w: Film i historia. Antologia, red. I. Kurz, Warszawa: Wydawnictwa Uniwersytetu Warszawskiego, s. $19-24$.

Misiak Anna (2006), Kinematograf kontrolowany. Cenzura filmowa w kraju socjalistycznym i demokratycznym (PRL i USA). Analiza socjologiczna, Kraków: Universitas.

Rosenstone Robert A. (2008), Historia w obrazach/historia w słowach: rozważania nad możliwościa przedstawienia historii na taśmie filmowej, przeł. Ł. Zaremba, w: Film $i$ historia. Antologia, red. I. Kurz, Warszawa: Wydawnictwa Uniwersytetu Warszawskiego, s. 93-114.

White Hayden (2008), Historiografia $i$ historiofotia, przeł. Ł. Zaremba, w: Film i historia. Antologia, red. I. Kurz, Warszawa: Wydawnictwa Uniwersytetu Warszawskiego, s. $117-127$.

White Hayden (2010), Przeszłość praktyczna, przeł. A. Czarnacka, w: Teoria wiedzy o przesztości na tle wspótczesnej humanistyki, red. E. Domańska, Poznań: Wydawnictwo Poznańskie, s. 49-73.

Zajiček Edward (1992), Poza ekranem. Kinematografia polska 1918-1991, Warszawa: Wydawnictwa Artystyczne i Filmowe.

Zwierzchowski Piotr (2013), Kino nowej pamięci. Obraz II wojny światowej w kinie polskim lat 60., Bydgoszcz: Wydawnictwo Uniwersytetu Kazimierza Wielkiego.

Zwierzchowski Piotr, Kornacki Krzysztof (2014), Metodologiczne problemy badania kina PRL-u, „Kwartalnik Filmowy”, nr 85 (145), s. 28-39. 


\title{
Past Supervised: \\ Historical Film in Polish People's Republic
}

\begin{abstract}
The article discusses Piotr Kurpiewski's book Historia na ekranie Polski Ludowej [History on the screen of Polish People's Republic]. Kurpiewski uses the concept of the politics of history to show the relationship between Polish postwar films and their political context. He examines the production process of individual films from the moment of their making to the moment(s) of their reception. From this point of view the historical film becomes one of the main ideological instruments, serving to legitimize the then sociopolitical regime.
\end{abstract}

Keywords: historical film, Polish People's Republic, visual history, ideology 